\title{
Bovine viral diarrhea virus infections in pigs: why is this situation important for Brazilian herds?
}

\author{
A infecção pelo vírus da diarreia viral bovina em suínos: \\ por que essa situação é importante para os rebanhos brasileiros?
}

\author{
Henrique Meiroz de Souza Almeida', Igor Renan Honorato Gatto', Anne Caroline Ramos dos \\ Santos', Daniele Araujo Pereira², Karla Alvarenga Nascimento², Thaís Gasparini Baraldi², \\ Marina Lopes Mechler ${ }^{1}$, Luís Guilherme de Oliveira ${ }^{2 *}$
}

\begin{abstract}
Swine can be infected by the bovine viral diarrhea virus (BVDV) under natural conditions. For this reason, further information and divulgation are needed regarding the pathogenicity of this virus in swine. This infection is practically unknown in the realm of pig farming, and, as it shares some similarities with the classical swine fever virus (CSFV), its diagnosis becomes a challenge for official sanitary programs. Studies have shown the absence of clinical signs in piglets and reproductive problems in sows due to BVDV infections. There is little research on the prevalence, risk factors, preventive measures and control of BVDV in pigs around the world. And in Brazil, the data is practically non-existent. At the time of diagnosis, comparing the most efficient laboratory tests such as virus neutralization, ELISA, RT-PCR, and immunofluorescence so as to minimize the risk of cross serological reactions when dealing with a persistent or transient infection, can be an important tool. Moreover, the practical implications for CSFV eradication programs are a main reason for the development of further research against this infection. Therefore, this paper aims to review various aspects of BVDV infection in pigs, and how this information can be important for Brazilian herds.
\end{abstract}

KEYWORDS: swine production; bovine viral diarrhea virus; pathogenesis; animal health protection; classical swine fever virus.

\begin{abstract}
RESUMO: O suíno pode ser infectado pelo vírus da diarreia viral bovina (BVDV) em condiçóes naturais, por isso são necessárias maiores informações e mais divulgação sobre a ação deste vírus nos suínos. Esta infecção é praticamente desconhecida na suinocultura e, devido a algumas semelhanças com vírus da peste suína clássica (VPSC), torna-se um desafio para os programas sanitários oficiais. Estudos revelam a ausência de sinais clínicos em leitôes ao mesmo tempo em que evidenciam problemas reprodutivos em porcas devido à infecção do BVDV. Poucas são as pesquisas sobre a prevalência, fatores de riscos, medidas de prevenção e controle do BVDV em suínos no mundo e, no Brasil, os dados são praticamente inexistentes. No diagnóstico, comparar os exames laboratoriais mais eficientes como a virusneutralização, ELISA, RT-PCR e imunofluorescência, diante de uma infecção persistente ou transitória, e assim minimizar o risco de reaçôes sorológicas cruzadas pode ser uma ferramenta fundamental. Ademais, as implicaçóes práticas em programas de erradicação da PSC são um grande motivo para o desenvolvimento de mais pesquisas frente a esta infecção. Portanto, este trabalho pretende revisar diversos aspectos da infecção do BVDV em suínos evidenciando o quanto essa situação pode ser importante para os rebanhos brasileiros.
\end{abstract}

PALAVRAS-CHAVE: suinocultura; vírus da diarreia viral bovina; patogenia; defesa sanitária animal; vírus da peste suína clássica. 


\section{INTRODUCTION}

Among the diseases affecting animal production, there are viral infections, which can be caused by the genus Pestivirus. These infections are extremely important, causing major economic and production losses worldwide. The genus Pestivirus has four species of viruses that are formally recognized: classical swine fever virus (CSFV), bovine viral diarrhea viruses 1 and 2 (BVDV-1 and BVDV-2), and border disease virus (BDV), in addition to one tentative species represented by an isolated from a giraffe (BECHER et al., 2003).

Recently BVDV-1 and BVDV-2 have become relevant to pigs, mainly because of classical swine fever, a foreign animal disease with serious consequences for the pig industry and the economy. The antigenic similarity between BVDV and CSFV can generate cross-reactivity in diagnostic tests and, altogether with similarity in clinical signs makes it very challengin to have a reliable diagnosis. Furthermore, data about the occurrence and prevalence of BVDV infections in pigs in Brazil are lacking, both in the pig industry and in non-technified swineherds, which can present several risk factors, including the lack of biosecurity measures and interspecies transmission.

The lack of data about the occurrence and prevalence of the disease in Brazil in conjunction with the great importance of the cross-reactivity between BVDV and CSFV, justify a paper like this, which aims to provide further information regarding the epidemiology of BVDV infections in pigs to contribute to the literature, and thus offer more technical data that is useful for surveillance and the classical swine fever eradication program.

\section{THE PESTIVIRUS GENUS AND ITS MOLECULAR BASIS FOR ANTIGENIC LIKENESS}

The genus Pestivirus from the Flaviviridae family consists of several viruses that are of great economic importance to livestock, and which were named according to the species of preferential infection (ASFOR et al., 2014). Some viruses infect different host species relatively easily (MOENNIG, 1990). The Bovine Viral Diarrhea Virus (BVDV) belongs to this genus and may present antigenic variations. In this case, phylogenetic analyses based on region 5' UTR and encoding the polyprotein gene NS23/p125 suggest the existence of two genotypes, BVDV-1 and BVDV-2. Furthermore, differences have been reported in the pathogenesis and antigenicity between genotypes. The BVDV-2 is more related to the most virulent and hemorrhagic form of the disease (RIDPATH et al., 1994).

Recently, a new species was isolated from fetal bovine serum in Brazil and currently it is being called "Hobi-like" worldwide. Due to its genetic and antigenic similarity to BVDV- 1 and BVDV-2, some researchers have suggested the virus be named BVDV-3, however there is no consensus yet among the scientific community (BAUERMANN et al., 2013). To the best of our knowledge, the presence of different genotypes of CSFV has not been reported in the scientific literature.

High genome similarity, high homology and serological cross-reactivity against monoclonal antibodies (MABs) indicate that there is an important resemblance between the Pestiviruses (VAN RIJN, 2007) and it is suggested that all of them emerged from a common ancestor virus (LIESS; MOENNIG, 1990). However, the genetic diversity of the Pestivirus genus results from successive mutations that occur because of the viral replication process and recombination with other homologous or heterologous RNAs (NAGAI et al., 2004). A phylogenetic analysis of a 268 nucleotide sequence within the $5^{\prime} \mathrm{UTR}$ of the viral genome resulted in the division of the BVDV into two genotypes: BVDV- 1 and BVDV- 2 (FLORES et al., 2000).

Envelope glycoprotein E2 of Pestivirus is the dominant protein in the host immune response, and the antibodies produced against this antigen are essential for diagnostic tests and for immunity, which is induced by vaccination (JELSMA et al., 2013). Molecular studies of the E2 glycoprotein help to unveil the origin of the serological cross-reactivity among the viruses of this genus. JELSMA et al. (2013) showed that the $\mathrm{B} / \mathrm{C}$ domains of the $\mathrm{E} 2$ glycoprotein in CSFV are analogous to the $\mathrm{N}$-terminal portion of the A domain of the E2 glycoprotein of BVDV, as the BVDV Z2 region is similar to part of the CSFV D/A domain, proving that despite being different species, the antigenic structure of these two pestivirus specimens is similar.

According to SANDVIK (2005), the E2 envelope glycoprotein is mainly responsible for antigenic similarity and difference between the Pestivirus. Research conducted by FLORES et al. (2000) indicated that the source of the antigenic differences between the strains and the BVDV sub-genotypes relates to variants of the glycoprotein gp53/E2 in the viral envelope. In spite of the fact that the information is relatively limited, it is believed that there is a great similarity between the antigenic sites of BVDV-1, BVDV-2 and CSFV (NEWCOMER; GIVENS, 2013).

Studies based on cross-reaction in virus neutralization tests identified six antigenic groups of Pestivirus [BVDV1, BVDV-2, BDV, CSFV, H138 (Giraffe- 1), and V60 (Reindeer-1)], with the most important being group I, which comprises four BVDV strains isolated from cattle and two BVDV strains isolated from pigs (DEKKER et al., 1995). RIDPATH et al. (2000) carried out virus neutralization tests using hyperimmune sera produced for different species of Pestivirus (BVDV-1, BVDV-2, BDV and CSFV), and tested each of these sera in the same species, noting the occurrence of neutralization between heterologous species with titers up to 1024 (sera anti-CSFV for BVDV-1) and 512 (sera anti-CSFV for BVDV-2). 
Interestingly, research conducted in vivo showed that pigs infected with BVDV had clinical resistance to the CSFV infection, likewise there was no detectable transmission of CSFV among pig herds due to the occurrence of a cross serological reaction (WIERINGA-JELSMA et al., 2006). As such, MENGELING et al. (1963a) demonstrate that bovine kidney cells infected with BVDV in cell culture showed fluorescence when brought into contact with anti-CSFV antibodies conjugated with fluorescein, confirming the antigenic similarity between the viruses of this genus.

Cross-reactivity in serological tests also occurs within the same species, since there is evidence that animals immunized with the vaccine for BVDV-1 can be protected against BVDV-2 and "Hobi-like" (DECARO et al., 2013). On the other hand, antigenic variation can occur within the same genotype (BVDV-1). When testing against a hyperimmune lamb serum, antigenic similarity rates (R) ranged from 1.1 to 50 among the subgenotype of BVDV-1 (ALPAY; YESILBAG, 2015).

\section{DIAGNOSTIC TESTS AND SEROLOGICAL CROSS-REACTIONS}

Laboratory tests are crucial in performing diagnoses of diseases that are caused by pestiviruses. They are also important in differentiating the etiologic agents of this genus. Diagnostic techniques that detect the presence of anti-BVDV antibodies in serum are considered more efficient, faster and cheaper when it comes to identifying animal exposure to the virus.

Viral isolation techniques can be used, but due to their laborious nature, the use of $\mathrm{PCR}$ can be a good alternative for detecting the viral agent (HOUE et al., 2006). Samples such as blood, milk, saliva and tissue can be successfully tested using RT-PCR (KLIUCINSKAS et al., 2008), and can be stored for prolonged periods of time with minimal effect (VILCEK et al., 2001).

A direct fluorescent antibody test (DFA) has been highlighted as an important diagnostic test for CSF because it can easily identify cells that are infected with CSFV in the cell culture, which is isolated from serum and blood samples from infected pigs (MENGELING et al., 1963b). However, pigs infected with BVDV may have false-positive DFA results, requiring the use of laborious and time-consuming confirmatory tests. Positive cases of CSF require the slaughter of the entire swine herd (WENSVOORT et al., 1989).

The virus neutralization test (VNT) is based on the identification and quantification of antibodies against the E2 envelope glycoprotein (SANDVIK, 2005). This technique is considered the reference test for the diagnosis of bovine viral diarrhea (OIE, 2015c) because of the several advantages it offers such as the ability to detect and quantify antibodies, its ability to test sera from different animal species, and its flexibility to use different genotypes/sub-genotypes of BVDV, thus increasing the power of the diagnostic test (DUBOVI, 2013).
According to DUBOVI (2013), the possibility of using any kind of serum in virus neutralization is essential. Because BVDV infects several animals in addition to cattle, there is the need for a test that assesses different types of serum. This is possible in VNT, which is considered the best test for the diagnosis of bovine viral diarrhea. For VNT, it is essential to test the serum for BVDV-1 and BVDV-2, since low titers of antibodies of BVDV-2 cannot be detected when performing VNT with the BVDV-1, and vice versa (OIE, 2015a). When performed according to standard protocols of OIE, virus neutralization is a very sensitive and specific test (SANDVIK, 2005), although these values differ between laboratories.

ELISA tests for the diagnosis of CSF have been developed using MABs, which are based on the detection of antibodies produced for E2 glycoprotein. In tests performed in seven ELISA commercial kits, with specificity ranging from 92 to $100 \%$ and sensitivity ranging from 51 to $100 \%$, only three commercial kits were able to differentiate anti-BVDV antibodies from anti-CSFV antibodies in the samples (SCHROEDER et al., 2012).

Reports of CSF outbreaks in the field showed that when ELISA is used as a primary diagnostic test, it can have false positive results, mainly in low antibody titer samples (DE SMIT et al., 1999). In all cases, it is necessary to use a second confirmatory test, which increases the time of action needed to focus contention.

The use of MABs has emerged as a possible solution to prevent cross reactions in serological tests. When testing polyclonal anti-CSFV front sera with 31 strains of BVDV and BDV and 94 strains of CSFV, all were reactive. While using anti-CSFV MABs there was no reaction with strains of BVDV and BDV (WENSVOORT et al., 1989). On the other hand, studies conducted at the same time claim that anti-BVDV MABs were reactive to $40 \%$ of the CSFV strains tested, however anti-CSFV MABs did not react to any other kind of Pestivirus, indicating a possible solution for the diagnosis of CSF. (CAY et al., 1989; EDWARDS et al., 1991). Regardless, further studies are needed.

\section{EPIDEMIOLOGICAL ISSUES OF BVDV INFECTIONS IN PIGS}

Despite the fact that ruminant Pestivirus infections in pigs are not as problematic as CSFV infections, distinguishing between these two diseases can sometimes be very difficult (PATON; DONE, 1994). Pestivirus infections in pigs are responsible for raising sanitary barriers between countries. Infection caused by BVDV in pigs have been reported in countries such as China (DENG et al., 2012), the Netherlands (LOEFFEN et al., 2009), Brazil (GATTO, 2015; ALMEIDA, 2015) and others, which draws up concerns about the existence of accurate diagnostic tests, questions about risk factors involved, and the BVDV's clinical form. 
The first report of isolation ruminant pestiviruses in naturally infected pigs occurred in 1973 (FERNELIUS et al., 1973). BVDV infections in pigs are usually asymptomatic, although in some cases, reproductive problems have been observed, such as birth of weak piglets, abortion, fetal mummification, hyperthermia and intestinal cramps (KIRKLANT et al., 2012; $\mathrm{TAO}$ et al., 2013). In pregnant sows, transplacental infection can cause abortions, stillbirths, the birth of weak piglets, malformations and even the birth of persistently infected piglets (PATON; DONE, 1994; BECHER et al., 2003).

Cases in which the BVDV infection induced a lot of injuries in pigs were caused by viral strains after serial passages and infections in this species. In piglets, BVDV infection has clinical signs, such as anemia, delayed development, rough coat, polyarthritis, congenital tremors, petechiae on the skin, diarrhea, conjunctivitis and cyanosis (TERPSTRA; WENSVOORT, 1988). Although, pigs' postnatal BVDV infection is considered harmless, the CSFV infection affects herds with high mortality (MOENNIG, 1990).

In England, there was an outbreak of sudden death in piglets with clinical signs that are similar to CSF, but the etiologic diagnosis was BVDV infection. The same agent was isolated from cattle on the same farm. The isolated virus was equally susceptible to neutralization from swine and cattle antibodies (PATON et al., 1992).

The prevalence of BVDV infection in pigs varies according to regions. In 11 Chinese provinces, the prevalence of sows with reproductive disorder was $20-30 \%$, and they had BVDV-1, the most prevalent genotype (DENG et al., 2012). In the Netherlands, the prevalence of positive cases was $0.42 \%$ in finishing pigs, $2.5 \%$ for sows and $11 \%$ of swine herds (LOEFFEN et al., 2009). In a study conducted in Poland, 14,608 pig sera collected between 2008 and 2011 were tested with ELISA, and BVDV was detected in 11 (68.75\%) out of the 16 provinces, and the seroprevalence varied from $0.1 \%$ to $1.04 \%$ (with an average of $0.31 \%$ ) (LIPOWSKI, 2014). Older data affirm that in countries declared free of CSF, the prevalence of BVDV infected pigs ranged from 1.6\% to $43.5 \%$ (JENSEN, 1985). However, a study of pig herds in the province of Ontario, Canada, did not identify any animal that was positive for BVDV (O'SULLIVAN et al., 2011).

Studies in Brazil are being conducted by our team, and preliminary results are very interesting. GATTO (2015) developed a study that aimed to detect anti-BVDV antibodies in finishing pigs slaughtered in the state of São Paulo. 817 swine blood samples were collected from animals in several Brazilian states. Virus neutralization tests were applied and the seroprevalence result of neutralizing anti-BVDV-1-Singer antibodies was $2.32 \%$. Taken together, two other studies were performed in swine from non-technified rearing farms (GATTO, 2015; ALMEIDA, 2015). In the first one, 412 samples of swine blood were collected in the city's slaughterhouse during the bleeding from pigs of 20 different small farms in the city of
Mossoró - Rio Grande do Norte State. Results showed that 9 out of 20 (45\%) farms had at least one positive animal. 4.13\% of the animals (17 pigs) were positive in the virus neutralization test (GATTO, 2015).

ALMEIDA (2015) focused on establishing the prevalence of non-technified rearing farms in the state of São Paulo. Serum samples of 360 swine, from 56 farms located in the northeast regions were collected and tested for virus neutralization using BVDV-1 strain Singer and BVDV-2 strain VS253 as the standard antigen. Only 17 samples were positive, presenting a prevalence of $4.72 \%$, and 15 farms had at least one positive animal, showing $26.79 \%$. When analyzing the genotypes separately, $1.94 \%$ was positive for BVDV- 1 and $3.06 \%$ for BVDV-2 strains.

Regarding transmission, epidemiological studies indicate that cattle are natural BVDV hosts, and are the major source of infection for pigs and other ruminants (KIRKLANT et al., 2012; RIDPATH, 2010). Direct contact with cattle on the same farm is considered the main source of BVDV transmission for pigs (KIRKLANT et al., 2012; LIESS; MOENNIG, 1990). Transmission can occur due to milk from infected cattle and other dairy products being fed to the pigs, from the use of contaminated CSF vaccines, and through fomites (CARBREY et al., 1976; TERPSTRA; WENSVOORT, 1988). Contrary to what was previously believed, transmission also occurs from one pig to another, although rarely (WIERINGA-JELSMA et al., 2006).

As such, DENG et al. (2012) claim that the prevalence of BVDV in pig herds is closely linked with the prevalence of the disease in cattle herds. Thus, they corroborate the conclusions of LOEFFEN et al. (2009) and O'SULLIVAN (2011), who attribute the low prevalence of BVDV in swineherds with the high level of animal production, which leads to the decline of farms with more than one animal species and reduces the contact between cattle and pigs. In addition to contact with cattle, others risk factors exist, as GATTO (2015) demonstrated in a study focused on evaluating the occurrence of anti-BVDV-2 antibodies and the associated risk factors in finishing pigs. Significant association was observed in the logistic regression with the risk factors: trucks were not washed and disinfected $(p=0.0077)$. Ultimately, more data is necessary to clarify important information about epidemiological issues of BVDV transmission in pig herds.

\section{IMPLICATIONS TOWARDS CLASSICAL SWINE FEVER ERADICATION PROGRAMMS}

Classical Swine Fever (CSF) is a foreign animal disease according to OIE (2014), since its occurrence leads to serious consequences for animal welfare, pig farming and the export of animals and animal products. It is a high mortality and morbidity disease and its severity often extends beyond national 
borders, bringing socio-economic losses, and making the international trade of pigs and their products difficult or impossible (BRASIL, 2004b). The Brazilian states of Rio Grande do Sul and Santa Catarina achieved recognition as Classical Swine Fever (CSF) free areas by the World Organisation for Animal Health in 2015 (OIE, 2015b).

In Brazil, CSF is a disease that activates animal health protection measures, and, as a result, the infected animals are euthanized. There is a contingency plan for if CSF were to reach the whole country, and all actions to be taken in an outbreak are established (BRASIL, 2004b). On the other hand, for states where CSF is controlled, there is a surveillance plan to perform in the swine productive system (BRASIL, 2015). Vaccination is prohibited throughout national territory. It is allowed only in specific cases, where there is a high risk of spreading the disease, and it requires authorization from the animal health authorities (BRASIL, 2004a).

Due to the antigen structure's similarity among the etiologic agents of CSF and BVD, cross-reactions in serological tests are likely to occur. Thus, the presence of anti-BVDV antibodies in pig serum can lead to false positive results of serologic tests for the diagnosis of CSF, causing problems in eradication programs of CSF or even in epidemiological surveys of this disease (LOEFFEN et al., 2009; TAO et al., 2013).

Although it is banned in Brazil (BRASIL, 2004a), the vaccination is a widely used strategy for CSF control and eradication programs. However, studies show that the presence of anti-BVDV antibodies in herds due to previous animal infection reduces the effectiveness of the vaccine against CSF (VAN RIJN, 2007), which results in a poor performance from the control and eradication programs. According to DE SMIT et al. (1999), eradication programs with poor diagnostic accuracy can lead to a delay in decision making, which leads to further spread of the disease and increased economic loss.
The presence of anti-BVDV antibodies in pig herds in the Netherlands hindered the control and diagnosis of positive animals during an outbreak of CSF in the 1990s, due to the occurrence of false-positives (DE SMIT et al., 1999). The main measure taken to prevent positive cases of CSF is the slaughtering of the animals. Even though it results in losses for the producer, a correct diagnosis is of utmost importance for disease control and eradication (WENSVOORT et al., 1989).

\section{CONCLUSION}

Among the items discussed in this review, the issue of Bovine Viral Diarrhea Virus infection in pigs is poorly known. It is believed that natural and experimental infection in pigs with BVDV can present similar pathogenesis in swine, cattle and sheep. However, there is no information that support this affirmation. Other points regarding seroconversion, prevalence, and diagnostics are being clarified. Finally, this review showed further work on BVDV infection in swine in order to elucidate specific information about this ruminant pathogen, which has still been poorly studied in pig farming. Additionally, it demonstrated the extent of BVDV particularities in pigs in order to differentiate them from CSF cases.

\section{ACKNOWLEDGEMENTS}

The authors would like to acknowledge the São Paulo Research Foundation, since our research on BVDV infections in pigs receives financial support from grant number 2014/13590-3.

| | | | | | | | || | | | | | | | | | | | | | | | | | | | | | | | | | | | | | | | | | | | | | | | | | | | | | | | | | | | | | | | | | | | | | | | | | | | | | | | | | | | | | | | | | | | | | | | | | | | | | | | | | | | | | | | | | | | | | | | | | | | | | | | | | | | | | | | | | | | | | | | | | | | | | | | | | | | | | | | | | | | | | | | | | | | | | | | | | | | | | | | | | | | | | | | | | | | | | | | | REFERENCES

\begin{abstract}
ALMEIDA, H.M.S. Epidemiologia e prevalência de infecções pelo Vírus da Diarreia Viral Bovina (BVDV) em suínos de criações não tecnificadas. 2015.43p. Dissertation (Mestrado) - Faculdade de Ciências Agrárias e Veterinárias de Jaboticabal, Universidade Estadual Paulista “Júlio de Mesquita Filho", Jaboticabal, 2015. Available from: <http://hdl.handle.net/1 1449/136047>. Accessed on: 2016 January.
\end{abstract}

ALPAY, G.; YESILBAG, K. Serological relationships among subgroups in Bovine Viral Diarrhea Virus genotype 1 (BVDV-1). Veterinary Microbiology, v.175, n.1, p.1-6, 2015.

ASFOR, A.S.; WAKELEY, P.R.; DREW, T.W.; PATON, D.J. Recombinant Pestivirus E2 glycoproteins prevent viral attachment to permissive and non-permissive cells with different efficiency. Virus Research, v.189, p.147-157, 2014.
BAUERMANN, F.V.; RIDPATH, J.F.; WEINBLEN, R.; FLORES, E.F. $\mathrm{HoBi}$-like viruses: and emerging group of Pestiviruses. Journal of Veterinary Diagnostic Investigation, v.25, n. 1, p.6-15, 2013.

BECHER, P.; RAMIREZ, R.A.; ORLICH, M.; ROSALES, S.C.; KÖNIG, M.; SCHWEIZER, M.; STALDER, H.; SCHIRRMEIER, H.; THIEL, H.J. Genetic and antigenic characterization of novel Pestivirus genotypes: implications for classification. Virology, v.311, p.96-104, 2003.

BRASIL. Ministério da Agricultura, Pecuária e Abastecimento. Instrução Normativa n 6, de 9 de março de 2004. Diário Oficial da União, Brasília, p.3, 2004a.

BRASIL. Ministério da Agricultura, Pecuária e Abastecimento. Instrução Normativa n 27, de 20 de abril de 2004. Diário Oficial da União, Brasília, p.7, 2004b. 
BRASIL. Ministério da Agricultura, Pecuária e Abastecimento. Programa Nacional de Sanidade dos Suídeos - PNSS. 2015. Available from: <http://www.agricultura.gov.br/assuntos/ sanidade-animal-e-vegetal/saude-animal/programas-de-saudeanimal/sanidade-suidea>. Accessed on: 2016 Apr. 15.

CARBREY, E.A.; STEWART, W.C.; KRESSE, J.I.; SNYDER, M.L. Natural infection of pigs with bovine viral diarrhea virus and its differential diagnosis from hog cholera. Journal of American Veterinary Association, v.169, p.1217-1219, 1976.

CAY, B.; CHAPPUIS, G.; COULIBALY, C.; DINTER, Z.; EDWARDS, S.; GREISER-WILKER, I.; GUNN, M.; HAVE, P.; HESS, G.; JUNTTI, N.; LIESS, B.; MATEO, A.; MCHUGH, P.; MOENNIG, V.; NETTLETON, P.; WENSVOORT, G. Comparative analysis of monoclonal antibodies against Pestiviruses: report of an international workshop. Veterinary Microbiology, v.20, p.123-129, 1989.

DE SMIT, A.J.; EBLÉ, P.L.; KLUIJVER, E.P.; BLOEMRAD, M.; BOUMA, A. Laboratory decision making during the classical swine fever epidemic of 1997-1998 in the Netherlands. Preventive Veterinary Medicine, v.42, p.185-199, 1999.

DECARO, N.; MARI, V.; SCIARRETTA, R.; LUCENTE, M.S.; CAMERO, M.; LOSURDO, M.; LARROCA, V.; COLAO, V.; CAVALIERE, N.; LOVERO, A.; LORUSSO, E.; BUONAVOGLIA, C. Comparison of the cross-antibody response induced in sheep by inactivated bovine viral diarrhoea virus 1 and Hobi-like Pestivirus. Research in Veterinary Science, v.94, p.806-808, 2013.

DEKKER, A.; WENSVOORT, G.; TERPSTRA, C. Six antigenic groups within the genus Pestivirus as identified by cross neutralization assay. Veterinary Microbiology, v.47, n.3-4, p.3 17-329, 1995.

DENG, Y.; SUN, C.Q.; CAO, S.J.; LIN, T.; YUAN, S.S.; ZHANG, H.B.; ZHAI, S.L.; HUANG, L.; SHAN, T.L.; ZHENG, H.; WEN, X.T.; TONG, G.Z. High prevalence of bovine viral diarrhea virus 1 in Chinese swine herds. Veterinary Microbiology, v. 159, p.490-493, 2012.

DUBOVI, E.J. Laboratory diagnosis of bovine viral diarrhoea virus. Biologicals, v.41, p.8-13, 2013.

EDWARDS, S.; MOENNIG, V.; WENSWOORT, G. The development of an international reference panel of monoclonal antibodies for the differentiation of hog cholera virus from other Pestiviruses. Veterinary Microbiology, v.29, n.2, p.101-108, 1991.

FERNELIUS, A.L.; AMTOWER, W.C.; LAMBERT, G.; MCCLURKIN, A.W.; MATTHEWS, P.J. Bovine viral diarrhoea virus in swine: characteristics of virus recovered from naturally and experimentally infected swine. Canadian Journal of Compared Medicine, v.37, p.13-20, 1973.

FLORES, E.F.; GIL, L.H.G.V.; BOTTON, S.A.; WEIBLEIN, R.; RIDPATH, J.F.; KREUTZ, L.C.; PILATI, C.; DRIEMEYER, D.; MOONJEN, V.; WENDELSTEIN, A.C. Clinical, pathological and antigenic aspects of Bovine Viral Diarrhea Virus (BVDV) type 2 isolates identified in Brazil. Veterinary Microbiology, v.77, n. 1-2, p. 175-183, 2000.

GATTO, I.R.H. Prevalência de anticorpos contra o vírus da diarreia viral bovina em suínos. 2015.76p. Dissertation (Mestrado) - Faculdade de Ciências Agrárias e Veterinárias de Jaboticabal, Universidade Estadual Paulista "Júlio de Mesquita Filho", Jaboticabal, 2015. Available from: <http://hdl.handle.net/1 1449/126461 >. Accessed on: 2016 January.
HOUE, H.; LINDBERG, A.; MOENNIG, V. Test strategies in bovine viral diarrhea virus control and eradication campaigns. Europe Journal of Veterinary Diagnostic Investigation, v. 18, p.427-436, 2006.

JELSMA, H.; LOEFFEN, W.L.A.; VAN BEUNINGEN, A.; VAN RIJN, P.A. Preliminary mapping of non-conserved epitopes on envelope glycoprotein E2 of Bovine Viral Diarrhea virus types 1 and 2. Veterinary Microbiology, v.166, p.195-199, 2013.

JENSEN, M.H. Screening for neutralizing antibodies against Hog cholera virus and/or bovine viral diarrhea virus in Danish pigs. Acta Veterinaria Scandinavica, v.22, p.72-80, 1985.

KIRKLANT, P.; LE POTIER, M.F.; VANNIER, P.; SINLAISON, D. Pestiviruses. In: ZIMMERMAN, J.J.; KARRIKER, L.; RAMIREZ, A.; SCHWARTZ, K.J.; STEVENSON, G.W. Diseases of Swine. $10^{\mathrm{a}} \mathrm{ed}$. Ames, lowa: Wiley-Blackwell, 2012. p.538-553.

KLIUCINSKAS, R.; LUKAUSKAS, K.; MILIUS, J.; VYSNIAUSKIS, G.; KLIUCINSKAS, D.; SALOMSKAS, A. Detection of bovine viral diarrhoea virus in saliva samples. Bulletin of the Veterinary Institute in Pulawy, v.52, p.31-37, 2008.

LIESS, B.; MOENNIG, V. Ruminant pestivirus infection in pig. Revue Scientifique et Technique, v.9, n.1, p.151-161, 1990.

LIPOWSKI, A. Serological study on bovine viral diarrhoea virus infection in pig population in Poland between 2008 and 2011. Bulletin of the Veterinary Institute in Pulawy, v.58, p.363-368, 2014.

LOEFFEN, W.L.A.; VAN BEUNINGEN, A.; QUAK, S.; ELBERS, A.R.W. Seroprevalence and risk factors for the presence of ruminant Pestiviruses in the Dutch swine population. Veterinary Microbiology, v.136, p.240-245, 2009.

MENGELING, W.L.; GUTEKUNST, D.E.; FERNELIUS, A.L.; PIRTLE, E.C. Demonstration of an antigenic relationship between Hog Cholera and Bovine Viral Diarrhoea viruses by immunofluorescence. Canadian Journal of Compared Medicine and Veterinary Science, v.27, n.7, p.162-164, $1963 a$.

MENGELING, W.L.; PIRTLE, E.C.; TORREY, J.P. Identification of Hog Cholera viral antigen by immunofluorescence. Application as a diagnostic and assay method. Canadian Journal of Compared Medicine and Veterinary Science, v.27, p.249-252, 1963b.

MOENNIG, V. Pestiviruses: a review. Veterinary Microbiology, v.23, p.35-54, 1990.

NAGAI, M.; HAYASHI, M.; SUGITA, S.; SAKODA, Y.; MORI, M.; MURAKAMI, T.; OZAWA, T.; YAMADA, N.; AKASHI, H. Phylogenetic analysis of bovine viral diarrhea viruses using five different genetic regions. Virus Research, v.99, n.2, p.103-113, 2004.

NEWCOMER, B.W.; GIVENS, M.D. Approved and experimental countermeasures against pestiviral diseases: Bovine viral diarrhea, classical swine fever and border disease. Antiviral Research, v.100, n.1, p.133-150, 2013.

O'SULLIVAN, T.; FRIENDSHIP, R.; CARMAN, S.; PEARL, D.L.; MCEWEN, B.; DEWEY, C. Seroprevalence of bovine viral diarrhea virus neutralizing antibodies in finisher hogs in Ontario swine herds and targeted diagnostic testing of 2 suspect herds. Canadian Veterinary Journal, v.52, p.1342-1344, 2011. 
PATON, D.J.; DONE, S.H. Congenital infection of pigs with ruminant-type Pestiviruses. Journal of Compared Pathology, v.111, p.151-163, 1994.

PATON, D. J.; SIMPSON, V.; DONE, S.H. Infection of pigs and cattle with Bovine Viral Diarrhoea Virus on a farm in England. Veterinary Record, v.131, p.185-188, 1992.

RIDPATH, J.F. Bovine viral diarrhea virus: global status. Veterinary Clinics of North America: Food Animal Practice, v.26, n. 1, p. 105$121,2010$.

RIDPATH, J.F.; BOLIN, S.R.; DUBOVI, E.J. Segregation of Bovine Viral Diarrhea Virus into genotypes. Virology, v.205, p.66-74, 1994.

RIDPATH, J.F.; NEILL, J.D.; FREY, M.; LANDGRAF, J.G. Phylogenetic, antigenic and clinical characterization of type 2 BVDV from North America. Veterinary Microbiology, v.77, p. 145-155, 2000.

SANDVIK, T. Selection and use of laboratory diagnostic assays in BVD control programs. Preventive Veterinary Medicine, v.72, p.3-16, 2005.

SANTOS, A.C.R. Experimental infection to evaluate the excretion of bovine viral diarrhea in weaned piglets and viral airborne transmission. 2016.42p. Dissertation (Mestrado) - Faculdade de Ciências Agrárias e Veterinárias de Jaboticabal, Universidade Estadual Paulista “Júlio de Mesquita Filho", Jaboticabal, 2016. Available from: <http://hdl. handle.net/1 1449/136407>. Accessed on: 2016 March.

SCHROEDER, S.; ROSEN, T.V.; BLOME, S.; LOEFFEN, W.; HAEGEMAN, A.; KOENEN, F.; UTTENTHAL, A. Evaluation of classical swine fever virus antibody detection assays with an emphasis on the differentiation of infected from vaccinated animals. Revue Scientifique et Technique, v.31, n.3, p.997-1010, 2012.

TAO, J.; LIAO, J.; WANG, Y.; ZHANG, X.; WANG, J.; ZHU, G. Bovine Viral Diarrhea Virus (BVDV) infection in pigs. Veterinary Microbiology, 2013.
TERPSTRA, C.; WENSVOORT, G. Natural infections of pigs with bovine viral diarrhoea virus associated with signs resembling swine fever. Research in Veterinary Science, v.45, p.137-142, 1988.

VAN RIJN, P.A. A common neutralizing epitope on envelope glycoprotein E2 of different Pestiviruses: Implications for improvement of vaccines and diagnostics for classical swine fever (CSF). Veterinary Microbiology, v.125, n.1-2, p.150-156, 2007.

VILČEK, Š.; STROJNY, L.; ĎURKOVIČ, B.; ROSSMANITH, W.; PATON, D. Storage of bovine viral diarrhoea virus samples on filter paper and detection of viral RNA by a RT-PCR method. Journal of Virological Methods, v.92, n.1, p.19-22, 2001.

WENSVOORT, G.; TERPSTRA, C.; KLUIJVER, E.P.; KRAGTEN, C.; WARNAAR, J.C. Antigenic differentiation of pestivirus strain with monoclonal antibodies against hog cholera virus. Veterinary Microbiology, v.21, p.9-20, 1989.

WIERINGA-JELSMA, T.; QUAK, S.; LOEFFEN, W.L. Limited BVDV transmission and full protection against CSFV transmission in pigs experimentally infected with BVDV type $1 \mathrm{~b}$. Veterinary Microbiology, v. 1 18, p.26-36, 2006.

WORLD ORGANIZATION FOR ANIMAL HEALTH (OIE). Bovine Viral Diarrhoea. In: _. Manual of Diagnostics Tests and Vaccines for Terrestrial Animals. 2015a. p.698-710. Available from: <http://www.oie.int/fileadmin/Home/eng/Health_standards/ tahm/2.04.07_BVD.pdf>. Accessed on: 2016 Apr. 04.

WORLD ORGANIZATION FOR ANIMAL HEALTH (OIE). Map of CSF official status. 2015b. Available from: <http://www.oie.int/ animal-health-in-the-world/official-disease-status/classical-swinefever/map-of-csf-official-status/>. Accessed on: 2016 Apr. 11.

WORLD ORGANIZATION FOR ANIMAL HEALTH (OIE). Terrestrial animal health code. $2015 \mathrm{c}$. Available from: <http://www.oie. int/en/international-standard-setting/terrestrial-code/accessonline/>. Accessed on: 2016 Apr. 04. 